\title{
ASO Author Reflections: Segment 8 Resections: Perhaps Not so Hidden...
}

\author{
Santiago López-Ben, MD \\ General Surgery, Hospital Universitari Dr Josep Trueta, Girona, Spain
}

\section{PAST}

The dome of the liver, namely, segment 8 , was for years hidden to the liver surgeon. To deal with this, some authors proposed to open the thoracic cavity, whereas others, mainly in Western countries, opted to perform formal right hepatectomy to ensure a safe resection. Refinement of cross-sectional images and a better understanding of liver anatomy allowed liver surgeons to develop different strategies to deal with more conservative solutions, either anatomic or non-anatomic, for segment 8 lesions.

\section{PRESENT}

Minimally invasive surgery, particularly its view, changed the way surgeons face surgical resections, as the magnified view and the need for a bloodless surgical field led to the development of different approaches to classical surgical resections. This has been especially true for segment 8 resections, with different approaches proposed to achieve an actual segment 8 resection. ${ }^{1-4}$ This report presents a venous-guided approach not based in a medial transection plane (middle hepatic vein or anterior fissure hepatic vein) but in a lateral plane (right hepatic vein), which can be useful for some particular anatomies. ${ }^{5}$

\section{FUTURE}

Similar to the medical oncologist, the liver surgical oncologist must be ready to offer tailored surgery to each particular patient based on his or her particular anatomic profile, either by a hilar approach or by different veinguided transfissural approaches for better achievement of surgical control.

\section{REFERENCES}

1. Kim JH. Pure laparoscopic anatomical resection of the segment 8 dorsal area using the transparenchymal Glissonean approach (video). Surg Oncol. 2019;31:99-100. https://doi.org/10.1016/j.su ronc.2019.10.004. Epub 4 October 2019. PMID: 31622917.

2. Kim JH, Kim H. Pure laparoscopic anatomic resection of the segment 8 ventral area using the transfissural Glissonean approach. Ann Surg Oncol. 2019;26:4608-9. https://doi.org/10.1245/s10434019-07852-4. Epub 3 October 2019. PMID: 31583544.

3. Ome Y, Honda G, Doi M, Muto J, Seyama Y. Laparoscopic anatomic liver resection of segment 8 using intrahepatic Glissonean approach. J Am Coll Surg. 2020;230:e13-e20. https://doi. org/10.1016/j.jamcollsurg.2019.11.008. Epub 201926 November. PMID: 31783094.

4. Berardi G, Igarashi K, Li CJ, Ozaki T, Mishima K, Nakajima K, Honda M, Wakabayashi G. Parenchymal-sparing anatomical liver resections with full laparoscopic approach: description of technique and short-term results. Ann Surg. 2019. https://doi.org/10. 1097/sla.0000000000003575. Epub ahead of print. PMID: 31460879.

5. López-Ben S, Albiol MT, Falgueras L, Caula C, Collado-Roura F, Castro E, et al. Pure laparoscopic anatomic resection of the segment 8 dorsal area using dorsal approach of right hepatic vein. Ann Surg Oncol. 2020. https://doi.org/10.1245/s10434-020-09462-x. Epub ahead of print.

Publisher's Note Springer Nature remains neutral with regard to jurisdictional claims in published maps and institutional affiliations.

First Received: 3 December 2020

Accepted: 3 December 2020;

Published Online: 6 January 2021

S. López-Ben, MD

e-mail: santilb@msn.com 